Article

\title{
Exploring Challenges and Solutions in Performing Employee Ecological Behaviour for a Sustainable Workplace
}

\author{
Khalid Farooq ${ }^{1}\left(\mathbb{D}\right.$, Mohd Yusoff Yusliza ${ }^{1, *(0)}$, Ratri Wahyuningtyas ${ }^{2}$, Adnan ul Haque $^{3}{ }^{\circledR}$, Zikri Muhammad $^{1}$ \\ and Jumadil Saputra $1, *$ (D) \\ 1 Faculty of Business, Economics and Social Development, Universiti Malaysia Terengganu, \\ Kuala Terengganu 21030, Malaysia; khalid_farooq_khan@yahoo.com (K.F.); zikri@umt.edu.my (Z.M.) \\ 2 Faculty of Economics dan Business, Universitas Telkom, Bandung 40257, Indonesia; tasaqratri3@gmail.com \\ 3 Faculty of Business, Yorkville University, 2000 Steeles Avenue, Concord, ON L4K 4N1, Canada; \\ ahaque@yorkvilleu.ca \\ * Correspondence: yusliza@umt.edu.my (M.Y.Y.); jumadil.saputra@umt.edu.my (J.S.)
}

check for

updates

Citation: Farooq, K.; Yusliza, M.Y.; Wahyuningtyas, R.; Haque, A.u.; Muhammad, Z.; Saputra, J. Exploring Challenges and Solutions in Performing Employee Ecological Behaviour for a Sustainable Workplace. Sustainability 2021, 13, 9665. https://doi.org/10.3390/ su13179665

Academic Editor: Hyo Sun Jung

Received: 6 August 2021

Accepted: 21 August 2021

Published: 27 August 2021

Publisher's Note: MDPI stays neutral with regard to jurisdictional claims in published maps and institutional affiliations.

Copyright: (c) 2021 by the authors. Licensee MDPI, Basel, Switzerland. This article is an open access article distributed under the terms and conditions of the Creative Commons Attribution (CC BY) license (https:// creativecommons.org/licenses/by/ $4.0 /)$.

\begin{abstract}
Organisations are a fundamental part of challenges and solutions to climate change issues. Therefore, the micro and macro factors influencing employee ecological behaviour (EEB) are a rising interest among researchers. The contemporary concept of EEB has been embraced by many organisations and attracted scholars' attention worldwide. Nevertheless, studies that explored challenges and solutions for performing EEB at the workplace are scarce. This study explored challenges and solutions in performing EEB at the workplace and focused on qualitative research methodology. The researchers interviewed 24 academicians from five leading green research Malaysian universities. Valuable qualitative data and numerous challenges such as high costs of practising, lack of infrastructure, top management support, environmental attitude, green mindfulness, enforcement, and monitoring were identified as challenges in applying EEB from the interviews. Stringent rules and regulations, monitoring, training programmes, and monetary incentives might be efficient solutions to apply ecological behaviour at workplaces, specifically universities. In conclusion, this study has discovered the challenges and solutions in implementing EEB for a sustainable workplace by interviewing academicians from different departments of selected Malaysian higher educational institutes. Also, poor infrastructure, high cost, and the lack of top management support, environmental attitude, green mindfulness, enforcement, and monitoring were identified as the primary challenges in performing EEB. Additionally, the research also discovered significant suggestions to resolve the challenges when implementing EEB at the workplace, such as strict rules and regulations, training programmes, incentives, monitoring, and communicating change and campaigns. Therefore, the stakeholders related to the industry should be concerned with the challenges identified when applying EEB at the workplace to apply the solutions generated from the study.
\end{abstract}

Keywords: employee ecological behaviour; challenges; higher educational institutes; sustainability workplace; solutions; Malaysia

\section{Introduction}

Governments and organisations worldwide have been implementing efficient measures to combat the rapid environmental degradation. Many governments have prescribed sustainable policies, whereas organisations adopt the policies to engage in environmentalfriendly workplace practices. The employees and the scope of their ecological behaviour determine the success of the practices [1,2]. Ecological behaviour is a standard effort in companies and employees that aids organisations and the environment [3]. According to environmental protection, the pressure to act according to environmental protection urges companies to implement ecological behaviour extensively in organisational work processes [4]. Scholarly studies on workplace ecological behaviours is an emerging research area [5-11]. Psychologists, scientists, and researchers phrase this behaviour similarly 
with terms such as "green behaviour", "sustainability behaviour", "pro-environmental behaviour", and "ecological behaviour", but all these terms highlight decreasing the implications inflicted by humans on the environment [12]. Ecological behaviour is described as actions that contribute towards environmental preservation and conservation [13].

EEB is exemplified as responsible or pro-environmental actions that display environmental sustainability appraisal, including decreasing waste and recycling resources [14]. These behaviours are intended to mitigate the detrimental impact on the ecosystem caused by human activities [15] and contribute to an environmentally sustainable workplace [16]. Thus, EEB is critical to organisations, regardless of sector, including tertiary education [17]. However, EEB studies lately highlight corporate sectors than the educational field [18]. For instance, EEB has been researched in hotels [14], manufacturing firms [19], fertilisers and chemicals [20], banking and financial sector [10,21] and multinational organisations [22].

Nevertheless, a research gap exists in the EEB field, specifically within the emerging research area of sustainability in higher education $[23,24]$. In addition, environmental management in Asian countries prone to the environmental crisis is overlooked [25]. Thus, EEB studies should be undertaken in developing countries, such as Malaysia, in higher educational institutes [18,26]. Furthermore, Malaysia faces critical environmental issues as an emergent economy. For example, Malaysia faces a higher than $6 \%$ annual growth average for carbon dioxide $\left(\mathrm{CO}_{2}\right)$ emissions that are not far from $7.42 \%$ of China's annual growth rate [18].

Prior researchers examined the predictors and outcomes of EEB for comprehending the creation of environmental-friendly and sustainable workplace. Several studies have associated individual-level factors to EEBs, such as subjective norms, pluralistic ignorance [27], employee-organisation fit [28], personal moral norms [1], moral reflectiveness and co-worker pro-environmental advocacy [29], environmental awareness, knowledge and concern [30]. In addition, certain studies focused on organisational-level influences, such as green human resource management practices [21], perceived corporate social responsibility [31], perceived organisational support [32], organisational climate [28], and incentives [33].

Conversely, numerous studies emphasised the outcome where EEB was found to significantly impact environmental performance [34], job satisfaction [35], intentions to implement green practices [36], sustainability [37], employee task performance [14], and employee self-esteem and well-being [8]. Nevertheless, barriers in applying EEB have posed a challenge to organisations' management [38]. Multiple barriers hinder employees from adopting green practices. Andersson, Shivarajan, and Blau [39] found that the context of exercising behaviours is directly linked to these barriers. For instance, utilities' cost could influence individuals at home, whereas employees do not regard this factor in the workplace [40]. Previous empirical studies have confirmed these contrasting behaviours. For example, Lee, De Young, and Marans [41] found that the same group of employees had a higher recycling rate at home than at the workplace.

In contrast, Lo, Peters, and Kok [42] revealed notable differences between energysaving behaviour within and outside the office. Several barriers to sustainable behaviours are linked to individual characteristics, while the rest depend on organisational setting [43,44]. Kim, Kim and Han [33] reported attitude towards ecological activities as a more significant barrier because obligations to perform such activities seem unlikely different for individuals at office and workplace [45]. Nonetheless, these studies were conducted in a specific context, such as energy-related behaviours and travelling behaviour [42], video conferencing and intentions to switch off personal computer when leaving office [33], and perceived satisfaction with current behaviours [46] with different perspectives. Unfortunately, no exploratory study has been conducted to examine the challenges in performing EEB at the workplace.

Yuriev, Boiral, Francoeur, and Paillé [38] undertook a systematic literature review and proposed that barriers hindering employees from implementing green behaviours should be explicitly investigated as no study was found to address this area. Additionally, Norton, 
Parker, Zacher, and Ashkanasy [43] focused on identifying the challenges faced by nonenvironmentally concerned employees in performing ecological behaviours. Furthermore, previous literature has identified that comprehensive data are lacking concerning the solutions to the challenges in EEB implementation within organisations. Nevertheless, no prior studies on EEB were undertaken to address solutions for sustainable workplaces within Malaysia. Thus, this study area is worth exploring as there is a proven scarcity of research concerning the challenges and solutions in implementing EEB practices for sustainable workplace establishment.

The researchers assessed five research higher educational institutes within Malaysia. The study aimed to examine the challenges that impede employees to perform ecological behaviour and identify solutions to address the challenges in implementing EEB for a sustainable workplace within Malaysian higher educational institutes. The underlying research questions $(\mathrm{RQ})$ research addressed were (i) What are the challenges that are impeding EEB? and (ii) What are the solutions to resolve the challenges in implementing EEB for a sustainable workplace in higher educational institutes? The motivation for using qualitative methods in this study is because it aligned with the research objective. Furthermore, the focus of qualitative methods is to gain an in-depth understanding of the hidden-embedded phenomenon [47]. In other words, the useful truth is established rather than only attaining mathematical objectivity [48]. Higher emphasis on the quantitative methods (numeric expressions) is incorrect as it would not always convey accurately the human feelings and opinions [47]. Quantitative methods if employed, the mathematical objectivity would be obtained will usefulness of the truth would still remain questionable. Thus, we employed qualitative methods in this study. In academics, it is not always a good practice to heavily rely on quantitative methods and therefore some subjective approaches should be employed to explore hidden embedded truth. Using the same arguments, the interview structure was designed.

The present study contributes to the body of literature by examining the underexplored topic concerning the challenges for performing EEB at the workplace that is critical for environmental sustainability. This study is also a pioneer study undertaken in a developing country that emphasises the importance of employees at an individual level for environment preservation. Furthermore, this study also acknowledged that the authors of [38] proposed research on challenges that hinder EEB at work as prior studies identifying obstacles of performing EEB at the workplace are limited. Similarly, some researchers only evaluated one or two EEB aspects. For example, Lo, van Breukelen, Peters, and Kok [49] only investigated employees' pro-environmental behaviour concerning communication and travelling mode, whereas Lo, Peters, and Kok [42] examined psychological determinants of office energy-related behaviour. Likewise, Ramus [50] only studied the perception of organisational support demonstrated via environmental policies communication. Furthermore, a systematic review by Yuriev, Boiral, Francoeur, and Paillé [38] discovered that specific attention was given to the "voluntary" and "discretionary" nature of behaviours, whereas EEB at the workplace is distinctive.

The following sections of the paper comprehensively explain the study. Section 2 addresses the literature review on EEB, challenges in performing EEB, and solution to implement EEB. Subsequently, the research methodology is discussed in Section 3, while Section 4 explains the findings and analysis. Finally, a thorough discussion, theoretical and practical implications, limitations and recommendations for future studies are explained in Section 5, whereas the conclusion is summarised in Section 6.

\section{Literature Review}

\subsection{Employee Ecological Behaviour (EEB)}

EEB is environmental-friendly or pro-environmental behaviour particular to workplaces [51] compared to individual green behaviour that refers to taking action to minimise negative implications on the environment or positively benefit environmental protection [52]. EEB directly associates environmental protection and other positive actions 
with conserving resources in daily organisational operations. EEB is defined as employee engagement in ecological behaviours, including employees' actions in performing environmentally-friendly work (e.g., recycling, rational resources usage, participation in environmental initiatives, and establishing green policies) by De Roeck and Farooq [53]. Ones and Dilchert [16] distinguished green behaviour as scalable actions and behaviours employees engage in that contribute or detract from environmental sustainability [54]. Thus, employees' sustainable behaviours consist of initiatives and actions [55], such as switching off lights to save energy when leaving offices, correcting documents electronically without printing to avoid waste, adopting teleconference instead of travelling to meetings for efficient resource utilisation, and recycling [56].

Employee green behaviour involves two aspects: task-related green behaviour implemented within employee responsibilities and proactive green behaviour implemented beyond employee responsibilities (Bissing-Olson et al. [57]) as stated by the autonomous standards of behaviour (organisational requirements and individual requirements selfdetermination). Task-related green behaviour denotes the green behaviour performed by employees when completing the core tasks demanded by organisations (e.g., environmental protection responsibilities stipulated in performing duties, compliance to environmental standards, and others). Discretionary and environmentally-friendly behaviour not clearly acknowledged by the formal reward system is known as proactive green behaviour [58]. Organisations encourage EEB to ensure the environmental management system is successfully implemented, and environmental performance achievement increases.

The ecological behaviours at workplaces are measurable behaviours that aid in accomplishing environmental sustainability in organisations [39]. The prevention of pollution and excessive carbon emissions, reusing or recycling, reducing energy used, and influencing others to adopt green initiatives are examples of ecological behaviours in the implementation of environmental management. Environmental psychologists agree that developing employee green behaviour motivation is significantly concerning [59]. However, encouraging sustainable behaviour among employees is an intimidating task because employees do not bear the cost of utilising resources in the workplace [60].

With the increase in environmental issues such as pollution, change in the climate, deforestation, natural resource overconsumption and so on the organizations are taking environmental concerns more often and direct mode by incorporating them into their corporate and competitive sustainable strategies [61,62].

Some of the solutions included voluntary environmental practices to attain competitive advantage while increasing financial performance [63]. In other words, the environmental management systems (EMS) are a solution to attain EEB, which is beneficial not only for the companies but also for the employees.

The study of Ababneh [64] revealed that employee engagement and personality attributes are significant factors for increasing green HRM practices as well as green behaviours. EEB is also significant in forming human capital as the employees learn to develop Green-HRM practices [65]. It helps in improving environmental management [66].

The corporate image of the company improves because of EEB as the Green-HRM implementations improve due to proper learning about effective and efficient environmental management [67-70]. Interestingly, EEB could improve green learning, which further improves their tendencies to adopt green behaviour [64]. This also leads to improving the organization's sustainable development [66].

\subsection{Challenges in Implementing Employee Ecological Behaviour (EEB)}

The researchers were motivated to undertake the research as available literature on the challenges in EEB is scarce. Nevertheless, previous studies were found to have specific challenges. The commonly reported barrier is the attitude towards pro-environmental activities [33,71]. Attitude involves the moral obligation to conduct pro-environmental activities, nature-concerned, and personal values that unlikely differ for individuals in the office and home [45]. Lack of environmental knowledge [30] and consciousness [72] among 
workers closely relate to individuals. Individuals' past experiences and habits influence the willingness to change behaviours in the workplace [73], which plays a part in the workers' willingness to act ecologically friendly in the office.

Several authors (e.g., Paillé et al. [74]; Blok et al. [24]) stated that organisations' green internal culture and management practices consider green behaviours the normality, and workers are prone to implement them. Likewise, employees are prone to act with responsibility when facilities and infrastructures offer greener options, such as parking, ecological-friendly food options, and self-adjusting air-conditioning are identified as easily accessible [32,73]. Several barriers, such as perception of the infrastructure, personal values, the time required, and social expectations, are part of employees' fundamental beliefs that impact the probability of conducting specific behaviours. Lamm et al. [75] empirically proved that employees are prone to act responsibly when organisations are acknowledged as green.

Paillé et al. [74] proposed that a workplace setting that nurtures employee readiness to act environmentally friendly could positively influence the probability of green behaviour in offices due to an increased awareness of corporate values and objectives. Yuriev et al. [38] disputed that insufficient internal resources such as financial, human capital, and time often hinder managers and employees from incorporating green initiatives. Ruepert et al. [71] assessed that several employees specified that they would frequently display pro-environmental actions in workplaces when organisations would establish the right conditions for acting upon their moral obligation feelings by securing adequate autonomy and control over pro-environmental behaviour. Boira et al. [72] asserted that managers who adopt green practices encourage their subordinates to act similarly.

\subsection{Solutions to Implement Employee Ecological Behaviour (EEB)}

A critical element observed in the literature indicates that employees must positively perceive corporate social responsibility to engage in green behaviours [14] through internal communication strategies to emphasise their standpoint on social responsibility [53]. Organisations could influence employees' green practices by establishing pro-sustainability strategies in their offices' design by utilising energy-efficient materials. For example, an office's layout and lighting design can considerably impact occupants' behaviour [76]. Environmental training and development denote a system of activities that encourage employees to study environmental conservation skills and focus on environmental issues critical in achieving environmental objectives [77]. Saeed et al. [6] discovered that environmental training could expand employees' awareness, knowledge, and skills results in improved employee's ecological behaviour.

Norton et al. [56] added the role of green psychological climate as a significant contributor of EEB in workplaces. A crucial contemporary challenge human resources professionals face is ensuring environmental sustainability's proper incorporation into human resource policies [78]. For instance, Saeed et al. [6] findings that green human resources management practices positively impacted employees' workplace ecological behaviour. Conversely, Leidner et al. [21] added that green human resource management practices are not peripheral, intermediate, or embedded but formed by sustainability advocates as they are critical when practising EEB in workplaces.

Besides this, the researchers identified the significant role of environment-specific transformational leadership and top management support as solutions in implementing ecological behaviour [79]. Yuriev et al. [38] offered insights for overcoming barriers by stating that individual perception is critical. For example, information on the environmental impact of specific behaviours (Greaves et al. 2013), such as driving against cycling to work, might inspire individuals to change their transportation mode. Similarly, an employee may feel "out-of-group" if the colleagues and managers leave the office in the dark at night, but the employee did not do the same. However, turning off lights is a discretionary behaviour. Furthermore, Lasrado and Zakaria [76] proposed introducing 
incentives, corrective pressure, and creating awareness through education as excellent strategies to encourage workplace ecological behaviour.

The existing literature that includes $[49,55,57]$ is primarily focusing on the quantitative approaches for examining EEB. It has focused on manufacturing units to attain mathematical objectivity. Furthermore, the existing literature has used a deductive approach to investigate the impact while there should be an absolute premise for the deductive approach. Therefore, an inductive approach should have been used. Similarly, the work of Yureiv et al. [38] and Ruepert et al. [71] has considered partially the use of green behavior in organizational settings but fails to incorporate the industry 4.0 drivers affecting EEB. The exploration from the human resource management lens is still under-explored.

\section{Materials and Methods}

The study aimed to conduct an exploratory analysis of the challenges that impede ecological behaviour among workplace employees. Exploratory qualitative research clarifies a phenomenon that has been limitedly studied to fill a literature gap [80]. Thus, a qualitative and inductive approach based on semi-structured interviews was adopted to undertake this study. The approach is suitable in examining the stakeholders' viewpoint on a specific topic within the context given [81]. Each participant was provided with an interview protocol approved by the ethics committee of the lead researchers' university before data collection. Participants were notified that their participation is voluntary, and they could withdraw from the study anytime. Informed signed consent was obtained from all the participants. The data was recorded via a digital computer base. The participants were assigned a pseudonym to preserve their anonymity [82] because the anonymity allowed them to freely provide the necessary information [83].

\subsection{Data Collection}

Semi-structured interviews were held with academicians from five public research universities in Malaysia to collect data for the study. The benefits of the semi-structured interview questionnaire are several, but the most important is that it allows the researchers to be more flexible in exploring the concepts and research phenomenon [48]. Structured questionnaires are rigid and often restrict the researchers in exploring hidden embedded research phenomenon as well as interlinked factors. Furthermore, the use of existing questionnaires increases the reliability and validity of the constructs in terms of content analysis. Hence, this research employed a similar approach. These five research universities were selected because they are top-ranked research universities in Malaysia as per the Quacquarelli Symonds (QS) ranking [84] and hold top positions at universities' Universitas Indonesia (UI) GreenMetric. The UI GreenMetric ranking aims to provide the latest conditions and policies related to green campus and sustainability in universities worldwide. The ranking is also expected to draw the attention of universities' leaders and stakeholders to combat the global climate crisis, water and energy conservation, recycling of waste, and green transportation [85].

Research universities must emphasise research and innovations due to competent academicians and competitive student admissions [86]. Besides, these universities are expected to explore their intellectual capacities and act as role models to other Malaysian universities in undertaking research activities focused on knowledge advancement. In addition, research universities are assigned to self-generate income and establish holding companies responsible for operating business ventures via the commercialisation of their research products.

\subsection{Participants}

The study used a convenient sample to choose the participants because flexibility was required as they were busy $[87,88]$. The participants were selected from diverse backgrounds and different university departments to comprehend the numerous challenges and solutions to apply EEB in workplaces. Convenience sampling was selected to assess 
the experiences and opinions of the universities' academicians with extensive knowledge and practical experience. Nevertheless, the participants must fulfil the primary criterion of being academicians and being involved in teaching activities in Malaysian research universities. Additionally, academic staff from the universities were available and ready to partake in the research. Conversely, data for the study were collected from February and August 2020.

\subsection{Data Analysis}

After obtaining informed consent from the participants, interviews were conducted and audio-recorded, with each session lasting $35 \mathrm{~min}$ to $90 \mathrm{~min}$. The data collected were analysed, stored in electronic format and subsequently, subjected to thematic content analysis procedures. Thematic analysis is a conventional practise in qualitative research involving searching through data to identify recurrent patterns. A "theme" is a cluster of linked categories that convey similar meanings and emerges through the inductive analytic process that characterises the qualitative paradigm [23]. The grounded theory approach that provided a standard framework for codifying, grouping, and comparing research evidence (Gioia et al. [81]) was the base for the data analysis. The grounded theory emphasises the analysis grounded in the data and recurring themes rather than testing pre-determined hypotheses, dissimilar to hypothetic deductive reasoning [89].

The analysis process adhered to a five-step approach: First, the interviews were transcribed verbatim and resulted in 75 pages of text with 1.5 line spacing. Secondly, the transcripts were assigned to different themes from data analysis and retrieval of relevant passages. Thirdly, a preliminary categorisation grid was established through a collaboration among the researchers. Subsequently, the transcripts were categorised according to the categorisation grid. The grid was refined throughout the data analysis process parallel to the inductive and iterative grounded theory approach. Then, new categories were created as new themes or concepts emerged. Several categories were subdivided or merged based on the data collected. Every category was comprehensively explained and deliberated among the researchers to enable data interpretation and enhance the validity of the analysis process. Fifth, the essential categories were gathered into two main themes encompassing the research objectives: the challenges for implementing EEB and solutions for EEB implications. Representative and illustrative passages concerning these themes were finally chosen. The results related to the study's specific objectives were relatively similar, although possible differences exist among the universities studied.

\section{Results}

This section displays the presentation and explains the data analysis. The findings and analysis were divided into two major parts: the challenges and solutions to apply ecological behaviour in workplaces within the Malaysian higher educational institutes. Table 1 shows the gender and academic qualification of the participants.

Table 1. Gender and academic qualification of the participants.

\begin{tabular}{cccccc}
\hline \multirow{2}{*}{ University } & \multirow{2}{*}{ Participants } & \multicolumn{2}{c}{ Gender } & \multicolumn{2}{c}{ Academic Qualification } \\
\cline { 2 - 6 } & & Male & Female & Master & PhD \\
\hline A & 7 & 4 & 3 & 1 & 6 \\
B & 3 & 2 & 1 & 1 & 2 \\
C & 3 & 1 & 2 & 1 & 2 \\
D & 6 & 4 & 2 & 1 & 5 \\
E & 5 & 3 & 2 & 1 & 4 \\
\hline Total $=5$ & 24 & 14 & 10 & 5 & 19 \\
\hline
\end{tabular}




\subsection{Challenges in Performing Employee Ecological Behaviour (EEB) at Workplace}

\subsubsection{Lack of Infrastructure}

The participants have unanimously recognised the lack of infrastructure in Malaysian higher educational institutes as a challenge in practising ecological behaviour at the workplace. Employees mainly worked within the existing infrastructure and opined a lack of infrastructure to practice eco-friendly behaviour. The participants highlighted several interesting findings as follows:

"This is because here we use centralised air conditioners. Centralised air conditioners are not sustainable [ ... ] you turn off your fans also; there is no breezy air in your room. In that regard, I am not satisfied." (University; A, Participant; 2)

"Car-free day was mean to minimise the carbon. You parked slightly far, and they provided bus services for you. The bus was not efficient, I mean the infrastructure was not able to support. So that is why it has been put on hold. It was practice for more than a year." (University; A, Participant; 3 )

One participant voiced out the following for saving electricity:

"When we designed this building, we proposed to the university that we wanted the half-light here instead of this kind of room, but the university did not accept that." (University; A, Participant; 3)

Lack of appropriate infrastructure precede non-ecological behaviours and were used to develop habits by offering distractive activity, as highlighted by another participant:

"The challenge here is monkeys. There are a lot of monkeys. Because of the monkeys, most lecturers will throw the trash in the toilets to avoid the monkeys from coming." (University; A, Participant; 1)

Another participant explained the lack of infrastructure as:

"One example is regarding throwing the rubbish. In my house, there are different types of dustbins. Here, there is no option. We use polystyrenes. In my institution, the air conditioners are centralised, so that's difficult for me. Sometimes they waste the energy." (University; A, Participant; 1)

Several other participants provided similar viewpoints that organisations should address the lack of infrastructure to ensure that employees are compliant with green practice requirements. Thus, the respondents acknowledge the lack of infrastructure as a significant challenge in performing ecological behaviour at the workplace.

\subsubsection{High Cost of Practising}

The participants also recognised the high costs of practising ecological behaviour as another significant challenge in performing ecological behaviours in organisations. All the participants stated that lack of budget in organisations would be a critical challenge in implementing eco-friendly activities. Individuals are not free to perform any environmental-friendly activity with limited budgets.

A participant stated:

"I only depend on centralised air conditioner. We already suggested to the management to change it many times, but they don't have any budget." (University; E, Participant; 1)

One of the participants summarised it as:

"I believe it's the budget allocation." (University; E, Participant; 2)

Another participant stated,

"[ ... W We used poly bags, and we managed to harvest 60 percent of paddy from the total. But actually, it is not us [...], because this project cost a lot of money, and we didn't have the money [ ... ] because, as you can see, nowadays, we don't have money." (University; D, Participant; 6) 
The remaining participants shared those high costs incurred to implement and maintain ecological behaviour practices are a challenge in the higher educational institutes.

\subsubsection{Lack of Top Management Support}

The lack of top management support is also acknowledged as a challenge for higher educational institutes in developing sustainable workplaces. Participants opined that the lack of managerial interest is a hindrance to EEB at the workplace. Interestingly, participants commonly mentioned that the lack of top management support is crucial for implementing EEB.

One participant acknowledged that top management support and involvement is essential for the implementation of EEB at the workplace:

"[ ... ] there are challenges. We can propose but to implement it needs involvement and support of other parties especially the top management." (University; B, Participant; 1)

Another participant asserted that:

"To me, the top management must be responsible for the implementation. If they do many campaigns, posting anywhere about green practices, green campus, then many people will become more aware." (University; D, Participant; 1)

Furthermore, the responses from the participants indicate that lack of top management support underlies their list of priorities:

"[ ... ] There are some initiatives, but I think those are not enough. They are busy with administrative matters, so sustainability issue is still there but is not their priority." (University; D, Participant; 6)

One participant added:

"[ ... ] The most we need to convince is top management. Sometimes after we started, they would stare at us for using less polystyrene, less plastic and serving using plates..." (University; A, Participant; 3)

\subsubsection{Lack of Environmental Attitude}

The participants also displayed their consensus on the importance of attitude for ecological behaviour practices at the workplace. Consequently, attitude towards EEB varies widely among employees.

"I think ecological behaviour relates to our attitude. As employees we have our workplace.

So, it is about how we interact with our work surrounding [ . . ]." (University; E, Participant; 3)

A participant stated that individuals who are deeply concerned about the environment are more likely to practice ways to conserve it:

[... I In higher education, I assume these are related to research activities, like planting the trees, and they involve lot of chemical. I think it is not only in technical part, but attitude, as in how to encourage attitude which is concerned about environmental sustainability [... ]. (University; D, Participant; 1)

One participant voiced out that:

"The attitude of course. Even though you have the awareness, if you don't want to be responsible, of course you will not do it." (University; D, Participant; 3)

One of the participants described the difficulties that occurred due to an irresponsible attitude. The participant utilised terms such as "lack of voluntary" and "little aspiration".

"[ . . . ] Lack of voluntary involvement and little aspiration to live in a better place and the attitude [ ... ]." (University; D, Participant; 3)

\subsubsection{Lack of Green Mindfulness}

The lack of mindfulness is also a significant challenge in performing ecological behaviour. Mindfulness represents the present condition of self-awareness and recognition, 
enabling individuals to wisely control their behaviour in the actual situation. The participants highlighted the lack of mindfulness in the environment as a barrier to performing EEB at the workplace. For example, as one participant stated:

"I want to save water. But the authority did not repair the cause of the wastage, such as a leaking pipe. So, you cannot stop the leak [... ] The authority needs to help, to fix everything [ ... ]." (University; D, Participant; 3)

Another participant added that individuals should wisely engage in controlling their behaviour instead of waiting for others to do so:

"We educate $[. .$.$] to turn off the tap when they see water being wasted, instead of$ waiting for others to do so. It all needs to start from individuals [ ... ]." (University; D, Participant; 2)

The same participant also added that:

"To me, as long we do our part [ ... ] we know that we have reduced the temperature of the air conditioner, we have switched off the lights when we go out, and we have been mindful." (University; D, Participant; 2)

Another participant added that:

"I do them because I am mindful of my responsibility as a human being [ . . ] When I switch on the lights, I will turn them off when not using them ... " (University; A, Participant; 2)

The remaining participants also voiced similar opinions that the lack of employees' environmental mindfulness could be a barrier to perform EEB in organisations. Thus, they acknowledged the absence of environmental mindfulness as one of the significant challenges for EEB.

\subsubsection{Lack of Enforcement and Monitoring}

The participants consensually agreed on the importance of enforcement and monitoring for EEB at the workplace. One of the participants said that:

"For me, I don't like to use the air conditioner. [ ... I I do not need recycled air. The initiative is there, but enforcement and monitoring are question marks." (University; A, Participant; 2)

In addition, the participant also added that:

"No, apart from what I told you, that campaign. For the river, I see the initiative, but the enforcement is very weak." (University; A, Participant; 2)

Another participant asserted as follows:

"They should do the enforcement. They should enforce the staff to do it. I believe that the guideline and the practices are already there. I think many people are aware, but they did it difficult to practice." (University; D, Participant; 3 )

One participant concluded with:

"We get sort of worried when the contractors come and don't follow our rules and regulations. They smoke cigarettes and we know our campus is a non-smoking zone. We feel like making reports because they don't respect our values. We want the rules to also be enforced on people coming from the outside." (University; E, Participant; 4)

\subsection{Solutions to Apply EEB at Workplace}

Five significant areas that could be addressed as solutions to apply EEB at workplaces in Malaysian universities were suggested in the interviews. The participants provided their justifications for the proposed solutions as discussed below.

\subsubsection{Strict Rules and Regulations}

The participants recognised strict rules and regulations as a practical solution when applying EEB at the workplace. They highlighted that: 
"I think the university should have a certain policy [ . . ] to contribute towards sustainability. For example, if the university decides to ban the use of plastic straws, the university should create a policy and call the cafeteria operators to inform them about the ban [ . . . ]." (University; D, Participant; 6)

The participant also added:

"Because in the end, awareness must be there, regulations must also be there. If you only have awareness, it will work in the short term, but in the long run the habit will comeback." (University; D, Participant; 6)

One participant stated as follows:

"If he feels there is an impact on him, then he'll do it. For example, if there's enforcement in the form of fines. It's like borrowing books from the library." (University; E, Participant; 5)

The participants also demanded that rules and regulations are also implemented for outsiders. For instance:

"We feel like making reports because they don't respect our values. We want the rules to also be enforced on people coming from the outside." (University; C, Participant; 1)

One more participant said that:

"None. Because there's little the staff can do even if they refuse to follow [ ... ]." (University; A, Participant; 6)

\subsubsection{Training Programmes}

The participants also agreed that training programmes are crucial solutions to apply EEB practices for a sustainable workplace:

"[ ... ] usually, it's the Campus Sustainability unit that holds talks and trainings. [...] there's a centre given the mandate to train Green Managers and the likes. The centre organises talks and proper workshops from time to time that are related to green practices [ . . . ." (University; C, Participant; 2)

The same participant further added that:

"There was a training for the administrative staff. I did not remember when, but I had to go to that place, organised by a professional team. They make series and courses for lecturers and staff, a mixture between environment and sustainability." (University; C, Participant; 2)

Another participant said:

"We also have held talks about climate, sustainability issue, and solid waste. We have a sustainability science course." (University; A, Participant; 5)

One participant asserted the importance of training for developing environmental knowledge:

"I got to see how people did the recycling things. I have never had a formal training in this [ . . . I think having enough knowledge is very important." (University; A, Participant; 2)

In addition, a fellow participant thought that training programmes were lacking: "[ ... ] I think that's one of the things we lack. There's less focus on training, more on immediate implementation." (University; C, Participant; 3)

\subsubsection{Incentives}

The participants unanimously viewed that monetary incentives would be efficient solutions to perform EEB at the workplace. For instance, a participant said that:

"A green experts, champion, idol, and icon could also be selected as incentives to those that have exceptionally adopting green in their daily routine to make example for others to follow wholeheartedly." (University; B, Participant; 2)

One participant added: 
"Yes, you'll get incentives if you do it. If you don't do it, it's okay." (University; A, Participant; 4)

Another participant emphasised monetary incentive,

"Because we care about the future [ . . ] To me, it is because it involves money [ . . ]."

(University; B, Participant; 3)

In addition, one participant linked monetary incentives with motivation by saying that:

"I think the factor relates to motivation and rewards. We may be motivated by what people around us do." (University; D, Participant; 5)

\subsubsection{Monitoring}

All the participants stated that organisations should monitor the activities of employees at the workplace:

"I think at University E they monitor everything. We must set the air conditioner at a certain temperature, switch off the lights during lunch time. They look at how much energy and cost have been saved." (University; D, Participant; 4)

A participant described:

"We also appoint energy manager, and sometimes they are the same person. Energy manager monitors the use of electricity at faculties, schools, and centres. Green manager looks into sustainability practices at these places. He or she encourages rubbish segregation, water conservation, and all that." (University; D, Participant; 5)

In addition, another participant said that:

"Monitoring should be there, kind of enforcement. It is more on the cafeteria owners. We can enforce on the owners not to use them." (University; A, Participant; 2)

A participant argued that:

"Through education and technology, people will be made aware of the damage if they do not do anything [ ... ] There are places that we cannot implement fully, such as the toilets. We will remind them through sensors [ ... ] We will see how to reduce cost, monitor which rooms have the lights turned on. We will use sensors for the temperature and electricity. [ . . . ]." (University; B, Participant; 2)

One participant also added:

"Each Responsibility Centre is responsible for managing the use of papers. [...] the budget has been reduced. Each centre needs to monitor." (University; E, Participant; 2)

\subsubsection{Communicating Change and Campaigns}

The participants mentioned communicating change in organisations as another factor to implement EEB at the workplace. For instance:

"They just encourage you, but they do not really provide any initiatives. They do not provide constant reminders." (University; A, Participant; 2)

In addition to that:

"In term of any formal communication about green work practices I don't think it is much communicated to us except about the car-free days [ ... ]." (University; A, Participant; 7)

The participants further included the importance of campaigns in addressing EEB. For example:

"Nothing, except that they provide you with dustbins. But they are supposed to have direct campaigns. [ ... ] A direct campaign will make people more aware. But, other than that, I have not heard about a campaign purposefully held for that." (University; A, Participant; 2)

One participant asserted that: 
"I think at the institutional level [ ... I If the institutions design the policy or practices or campaign, the scope will be wide. If everyone follows the practices, we will see the impact." (University; D, Participant; 4)

\section{Discussion}

This research provides a comprehensive understanding of EEB, a relatively new research area in the human resource management field. A gap exists in the literature related to EEB practices in Malaysian higher education institutes. However, literature is available regarding the implementation and determinants of EEB in the corporate sector. This study adds to sustainable higher education and environmental management by providing insights into the challenges that hinder employees from performing EEB and how to overcome the relatively new obstacles. The findings are essential for academicians and practitioners. The following subsections discuss the theoretical and managerial implications of this study.

The current study contributes to the literature from a theoretical perspective by expanding knowledge in green management, an ongoing global concern. Numerous scholars have encouraged the implementation of EEB in workplaces to achieve organisation sustainability (i.e., environmental, economic, and social) goals. Nevertheless, the challenges to perform EEB have been limitedly explored. The study identified several critical challenges to applying EEB at the workplace, such as the lack of infrastructure to practice EEB in Malaysian higher educational institutes. The lack of infrastructure for EEB that previous studies have not acknowledged is among the significant contributions of the current research to the literature on EEB.

Conversely, the study found that the lack of top management support, environmental attitude, mindfulness, enforcement and monitoring, and high costs incurred in practising EEB are significant challenges in implementing EEB at the workplace within higher educational institutes. Our findings are aligned with previous studies $[57,61,68]$. Graves et al. [79] also emphasised that top management who are committed to the environment strongly exhibit EEB at the workplace. The lack of top management support creates an adverse effect on environmental commitment. We confirm the work of Graves et al. [79] through our findings. Our findings support the previous notion of numerous researchers have identified environmental attitude as a significant predictor for ecological behaviour [56,57]. Tariq et al. [7] added that environmental attitude initiates different actions by employees in protecting the environment from deterioration. This is also supported by the present findings.

Another significant contribution of the present research is identifying green mindfulness that strongly inspires EEB at the workplace. Nevertheless, no prior green mindfulness study was discovered in the workplace context. However, the results are consistent with related studies on green mindfulness and pro-environmental behaviour at hotels [90]. The outcome suggests green mindfulness as a quasi-behaviour. Employees aware of environmental well-being would throw rubbish in the right bin and use water and energy sensibly at the workplace. The lack of green mindfulness creates an adverse effect in performing EEB. Employees with a lack of green mindfulness will not ensure that their actions during job performance do not breach the environmental regulations or manage the environmental crisis. The lack of enforcement and monitoring at the workplace also affects EEB. The result parallels prior studies that discovered a positive relationship between enforcement and monitoring as an essential strategy to promote EEB [76]. The participants mentioned that EEB is not voluntarily practised by people typically. Monitoring and enforcement assist in educating employees on behaving eco-friendly consistently.

The research also identified solutions that can be used to apply EEB at the workplace. For instance, imposing strict rules and regulations can be essential solutions when implementing EEB in the workplace. The participants highlighted this point by arguing that defining responsibilities to employees in the workplace will provide them with an understanding of what to do. The employees will adhere to EEB practices if there are guidelines provided. Similarly, the implementation of EEB will not be successful unless 
clear rules and regulations guide employees' actions. The findings are consistent with Lasrado and Zakaria's [76] and Islam et al. [91].

Nevertheless, environmental training to create knowledge and awareness as a strategy in promoting EEB was acknowledged in the previous studies conducted by Lasrado and Zakaria [66] and Saeed et al. [6]. Alternatively, this study also discovered monetary incentives as an element to promote EEB at the workplace. The discovery is consistent with the findings of Leidner et al. [21]. Nevertheless, this study also found that monitoring EEB activities after organisations' establishment would be crucial in ensuring continuous progress in practising EEB at the workplace. Finally, the study identified that communicating change and campaigns to perform EEB would efficiently promote EEB at the workplace. The findings are consistent with the outcomes of Lasrado and Zakaria [76], who revealed that visual reminders, campaigns, and consistent communication in the form of mail, pictures, or newsletters could also assist in changing the behaviour.

The research outcomes offer evidence-based consequences to university stakeholders on the significance and contributions of multiple challenges and solutions to perform EEB at the workplace. The findings will aid university policymakers to shape EEB among academic staff. Additionally, the study also assists management to comprehend the challenges and solutions to practice EEB to create sustainable workplaces. The research is also beneficial to the industry and the government planners in identifying challenges and adopting initiatives to overcome the challenges in developing a sustainable workplace. Environmental training programmes to increase environmental awareness and knowledge are crucial because environmentally concerned employees are more likely to adopt ecological behaviour. Nevertheless, the findings also proposed that increasing academic staff motivation by sharing environmental responsibilities and rewarding them for positive environmental gestures will encourage them to adopt additional environmental initiatives within the campus.

Similarly, the top management support for greener initiatives can assist policymakers in benefiting from academic staff's skills and expertise to provide solutions for environmental issues on the campus. Organisations can promote EEB in their employees by providing appropriate infrastructure, budgets for green initiatives, top management support, and recognition or rewards. The outcome also highlighted that developing strict rules and regulations to enhance EEB at the workplace is an efficient strategy. Besides, monitoring employees' activities is also essential for a successful EEB implementation. Additionally, proper communication and campaigning activities, such as recycling day, cleaning campaign, or a car-free day will provide a platform for academic staff to engage in EEB. Encouraging them to participate in such activities in the future is advantageous to improve the university's environmental awareness.

\section{Conclusions, Implications, and Future Recommendations}

Higher education institutions have acknowledged that overlooking human or behavioural factors in adopting environmental initiatives will result in inefficient environmental performance as environmental responsibility is increasingly recognised. Nevertheless, scarce research is available to guide the efficient implementation of environment-friendly initiatives through behavioural interventions. The current research is a pioneer in linking the challenges and solutions to performing EEB in the workplace that emphasise academic staff's EEB. The study has discovered the challenges and solutions to implementing EEB for a sustainable workplace by interviewing academicians from different departments of selected Malaysian higher educational institutes. Poor infrastructure, high cost, and the lack of top management support, environmental attitude, green mindfulness, enforcement, and monitoring were identified as the primary challenges in performing EEB. Additionally, the research also discovered significant suggestions to resolve the challenges when implementing EEB at the workplace, such as strict rules and regulations, training programmes, incentives, monitoring, and communicating change and campaigns. Therefore, the stake- 
holders related to the industry should be concerned with the challenges identified when applying EEB at the workplace to apply the solutions generated from the study.

The methodological and theoretical limitations in the study offer opportunities for future studies. Firstly, this research is limited as an exploratory study because the researchers only engaged in face-to-face interviews for the qualitative approach adopted. Future studies should adopt diverse techniques such as participant observations and case studies to conduct data triangulation that is complemented by a mixed-methodology approach (i.e., survey usage) to increase the robustness of the qualitative methodology. In addition, the researchers utilised the qualitative method to enhance the dynamic of exchanges and information sharing among the participants to create interactive dialogues. Future studies can employ these factors for empirical analysis.

Organisations are culturally, socially, economically, and environmentally embedded and impact numerous organisational aspects. The external environment has been argued to exert a series of institutional pressures on organisations that can be regulatory, normative, and socio-cultural. The organisational culture responds to the pressures in ways that have proven to be minimally adaptive gradually [23]. Thus, the external context of organisations should be critically considered, and emulating this study across boundaries in a cross-cultural setting will assist in establishing globally relevant EEB measures for higher education institutes.

The academic staff of universities was the target population of this research. Nevertheless, universities comprise a large population with complex activities that can affect the implementation of a sustainable workplace within the campus. Trans-disciplinary involvement of the top management, faculties, students, and other staff is crucial to improve the university's overall environmental performance. Future research should also examine non-academic staff, including administrative, technical, and operational staff, due to different employees' perceptions. Although our findings arrived at proposing the probable solutions to overcome the challenges, nonetheless, not all types of different solutions would present identical levels of effectiveness nor could they be applied equally, thus, future studies should consider the framework to assess and apply each challenge separately. We recommend that future studies on the subject should direct their approach towards elaborating a more specific action matrix aimed at specific types of organizations. By doing so, future studies would have more specificity and higher accuracy in identifying and responding to those varying challenges.

Author Contributions: Conceptualisation, K.F., M.Y.Y. and R.W.; methodology, M.Y.Y., Z.M., J.S. and A.u.H.; validation, K.F., M.Y.Y. and Z.M.; formal analysis, K.F., M.Y.Y., J.S. and R.W.; investigation, K.F., M.Y.Y., Z.M. and R.W.; resources, K.F., M.Y.Y. and Z.M.; data curation, K.F., M.Y.Y., A.u.H. and Z.M.; writing - original draft preparation, K.F., M.Y.Y., R.W. and Z.M.; writing-review and editing, M.Y.Y., A.u.H., J.S. and Z.M.; supervision, M.Y.Y. and Z.M.; project administration, M.Y.Y. and Z.M.; funding acquisition, M.Y.Y.; revising and addressing comments, A.u.H. All authors have read and agreed to the published version of the manuscript.

Funding: This research was funded by the Ministry of Higher Education Malaysia, Fundamental Research Grant Scheme (FRGS) No. FRGS/1/2019/SS03/UMT/02/3 and The APC was funded by Universiti Malaysia Terengganu.

Institutional Review Board Statement: Not applicable.

Informed Consent Statement: Not applicable.

Data Availability Statement: Not applicable.

Acknowledgments: We would like to thank the Centre for Research and Innovation Management (CRIM), Universiti Malaysia Terengganu that has supported this research publication. We also thank the Universitas Telkom and Yorkville University, for this excellent collaboration work and everyone who has volunteered to participate in this research.

Conflicts of Interest: The authors declare no conflict of interest. 


\section{References}

1. Fawehinmi, O.; Yusliza, M.Y.; Wan Kasim, W.Z.; Mohamad, Z.; Sofian Abdul Halim, M.A. Exploring the interplay of green human resource management, employee green behavior, and personal moral norms. SAGE Open 2020, 10. [CrossRef]

2. Ahmad, N.; Ullah, Z.; Arshad, M.Z.; waqas Kamran, H.; Scholz, M.; Han, H. Relationship between corporate social responsibility at the micro-level and environmental performance: The mediating role of employee pro-environmental behavior and the moderating role of gender. Sustain. Prod. Consum. 2021, 27, 1138-1148. [CrossRef]

3. Chaudhary, R. Green Human Resource Management and Employee Green Behavior: An Empirical Analysis. Corp. Soc. Responsib. Environ. Manag. 2020, 27, 630-641. [CrossRef]

4. Gao, L.; Wang, S.; Li, J.; Li, H. Application of the extended theory of planned behavior to understand individual's energy saving behavior in workplaces. Resour. Conserv. Recycl. 2017, 127, 107-113. [CrossRef]

5. Norton, T.A.; Zacher, H.; Ashkanasy, N. Organisational sustainability policies and employee green behaviour: The mediating role of work climate perceptions. J. Environ. Psychol. 2014, 38, 49-54. [CrossRef]

6. Bin Saeed, B.; Afsar, B.; Hafeez, S.; Khan, I.; Tahir, M.; Afridi, M.A. Promoting employee's proenvironmental behavior through green human resource management practices. Corp. Soc. Responsib. Environ. Manag. 2018, 26, 424-438. [CrossRef]

7. Tariq, M.; Yasir, M.; Majid, A. Promoting employees' environmental performance in hospitality industry through environmental attitude and ecological behavior: Moderating role of managers' environmental commitment. Corp. Soc. Responsib. Environ. Manag. 2020, 27, 3006-3017. [CrossRef]

8. Zhang, B.; Yang, L.; Cheng, X.; Chen, F. How Does Employee Green Behavior Impact Employee Well-Being? An Empirical Analysis. Int. J. Environ. Res. Public Health 2021, 18, 1669. [CrossRef]

9. Kong, L.; Sial, M.; Ahmad, N.; Sehleanu, M.; Li, Z.; Zia-Ud-Din, M.; Badulescu, D. CSR as a potential motivator to shape employees' view towards nature for a sustainable workplace environment. Sustainability 2021, 13, 1499. [CrossRef]

10. Rubel, M.R.B.; Kee, D.M.H.; Rimi, N.N. The influence of green HRM practices on green service behaviors: The mediating effect of green knowledge sharing. Empl. Relat. 2021, 43, 996-1015. [CrossRef]

11. Uddin, M.A.; Biswas, S.R.; Bhattacharjee, S.; Dey, M.; Mahmood, M. Inspiring employees' ecological behaviors: The roles of corporate environmental strategy, biospheric values, and eco-centric leadership. Bus. Strat. Environ. 2021, 30, $2367-2381$. [CrossRef]

12. Dahiya, R. Does organisational sustainability policies affect environmental attitude of employees? The missing link of green work climate perceptions. Bus. Strat. Dev. 2020, 3, 395-403. [CrossRef]

13. Axelrod, L.J.; Lehman, D.R. Environmstal rsYCnOLO Responding to Environmental Concerns. J. Environ. Psychol. 1993, 13, 149-159. [CrossRef]

14. He, J.; Morrison, A.M.; Zhang, H. Being sustainable: The three-way interactive effects of CSR, green human resource management, and responsible leadership on employee green behavior and task performance. Corp. Soc. Responsib. Environ. Manag. 2020, 28, 1043-1054. [CrossRef]

15. Stern, P.C. Toward a Coherent Theory of Environmentally Significant Behavior. J. Soc. Issues 2000, 56, 407-424. [CrossRef]

16. Ones, D.S.; Dilchert, S. Environmental Sustainability at Work: A Call to Action. Ind. Organ. Psychol. 2012, 5, 444-466. [CrossRef]

17. Yusliza, M.; Amirudin, A.; Rahadi, R.; Athirah, N.N.S.; Ramayah, T.; Muhammad, Z.; Mas, F.D.; Massaro, M.; Saputra, J.; Mokhlis, S. An Investigation of Pro-Environmental Behaviour and Sustainable Development in Malaysia. Sustainability 2020, $12,7083$. [CrossRef]

18. Anwar, N.; Mahmood, N.H.N.; Yusliza, M.Y.; Ramayah, T.; Faezah, J.N.; Khalid, W. Green Human Resource Management for organisational citizenship behaviour towards the environment and environmental performance on a university campus. J. Clean. Prod. 2020, 256, 120401. [CrossRef]

19. Bodrud-Doza, M.; Shammi, M.; Bahlman, L.; Islam, A.R.M.T.; Rahman, M. Psychosocial and Socio-Economic Crisis in Bangladesh Due to COVID-19 Pandemic: A Perception-Based Assessment. Front. Public Health 2020, 8, 341. [CrossRef]

20. Ansari, N.Y.; Farrukh, M.; Raza, A. Green human resource management and employees pro-environmental behaviours: Examining the underlying mechanism. Corp. Soc. Responsib. Environ. Manag. 2020, 28, 229-238. [CrossRef]

21. Leidner, S.; Baden, D.; Ashleigh, M. Green (environmental) HRM: Aligning ideals with appropriate practices. Pers. Rev. 2019, 48, 1169-1185. [CrossRef]

22. Dumont, J.; Shen, J.; Deng, X. Effects of Green HRM Practices on Employee Workplace Green Behavior: The Role of Psychological Green Climate and employee green values. Hum. Resour. Manag. 2017, 56, 613-627. [CrossRef]

23. Dumitru, A.; De Gregorio, E.; Bonnes, M.; Bonaiuto, M.; Carrus, G.; Garcia-Mira, R.; Maricchiolo, F. Low carbon energy behaviors in the workplace: A qualitative study in Italy and Spain. Energy Res. Soc. Sci. 2016, 13, 49-59. [CrossRef]

24. Blok, V.; Wesselink, R.; Studynka, O.; Kemp, R. Encouraging sustainability in the workplace: A survey on the pro-environmental behaviour of university employees. J. Clean. Prod. 2015, 106, 55-67. [CrossRef]

25. Renwick, D.W.S.; Redman, T.; Maguire, S. Green Human Resource Management: A Review and Research Agenda. Int. J. Manag. Rev. 2012, 15, 1-14. [CrossRef]

26. Fawehinmi, O.; Yusliza, M.-Y.; Mohamad, Z.; Faezah, J.N.; Muhammad, Z. Assessing the green behaviour of academics: The role of green human resource management and environmental knowledge. Int. J. Manpow. 2020, 41, 879-900. [CrossRef]

27. Chumg, H.-F.; Shi, J.-W.; Sun, K.-J. Why Employees Contribute to Pro-Environmental Behaviour: The Role of Pluralistic Ignorance in Chinese Society. Sustainability 2019, 12, 239. [CrossRef] 
28. Xiao, J.; Mao, J.-Y.; Huang, S.; Qing, T. Employee-Organization Fit and Voluntary Green Behavior: A Cross-Level Model Examining the Role of Perceived Insider Status and Green Organizational Climate. Int. J. Environ. Res. Public Health 2020, 17, 2193. [CrossRef] [PubMed]

29. Afsar, B.; Umrani, W.A. Corporate social responsibility and pro-environmental behavior at workplace: The role of moral reflectiveness, coworker advocacy, and environmental commitment. Corp. Soc. Responsib. Environ. Manag. 2019, 27, 109-125. [CrossRef]

30. Chan, E.S.W.; Hon, A.H.Y.; Okumus, F.; Chan, W. An empirical study of evironmental practices and an empirical study of environmental practices and employee ecological behavior in the hotel industry. J. Hosp. Tour. Res. 2014, 41, 585-608. [CrossRef]

31. Shah, S.H.A.; Cheema, S.; Al-Ghazali, B.M.; Ali, M.; Rafiq, N. Perceived corporate social responsibility and pro-environmental behaviors: The role of organizational identification and coworker pro-environmental advocacy. Corp. Soc. Responsib. Environ. Manag. 2020, 28, 366-377. [CrossRef]

32. Manika, D.; Wells, V.; Gregory-Smith, D.; Gentry, M. The Impact of Individual Attitudinal and Organisational Variables on Workplace Environmentally Friendly Behaviours. J. Bus. Ethic 2013, 126, 663-684. [CrossRef]

33. Graves, L.M.; Sarkis, J.; Zhu, Q. How transformational leadership and employee motivation combine to predict employee proenvironmental behaviors in China. J. Environ. Psychol. 2013, 35, 81-91. [CrossRef]

34. Kim, W.G.; McGinley, S.; Choi, H.-M.; Agmapisarn, C. Hotels' environmental leadership and employees' organizational citizenship behavior. Int. J. Hosp. Manag. 2019, 87, 102375. [CrossRef]

35. Kim, A.; Kim, Y.; Han, K. A Cross Level Investigation on the Linkage Between Job Satisfaction and Voluntary Workplace Green Behavior. J. Bus. Ethic 2018, 159, 1199-1214. [CrossRef]

36. Chan, E.S.W.; Hon, A.H.; Chan, W.; Okumus, F. What drives employees' intentions to implement green practices in hotels? The role of knowledge, awareness, concern and ecological behaviour. Int. J. Hosp. Manag. 2014, 40, 20-28. [CrossRef]

37. Amrutha, V.; Geetha, S. A systematic review on green human resource management: Implications for social sustainability. $J$. Clean. Prod. 2019, 247, 119131. [CrossRef]

38. Yuriev, A.; Boiral, O.; Francoeur, V.; Paillé, P. Overcoming the barriers to pro-environmental behaviors in the workplace: A systematic review. J. Clean. Prod. 2018, 182, 379-394. [CrossRef]

39. Andersson, L.; Shivarajan, S.; Blau, G. Enacting Ecological Sustainability in the MNC: A Test of an Adapted Value-Belief-Norm Framework. J. Bus. Ethic 2005, 59, 295-305. [CrossRef]

40. Siero, S.; Boon, M.; Kok, G.; Siero, F. Modification of driving behavior in a large transport organization: A field experiment. J. Appl. Psychol. 1989, 74, 417. [CrossRef]

41. Lee, Y.-J.; de Young, R.; Marans, R.W. Factors influencing individual recycling behavior in office settings: A study of office workers in Taiwan. Environ. Behav. 1995, 27, 380-403. [CrossRef]

42. Lo, S.H.; Peters, G.Y.; Kok, G. Energy-related behaviors in office buildings: A qualitative study on individual and organisational determinants. Appl. Psychol. 2012, 61, 227-249. [CrossRef]

43. Norton, T.A.; Parker, S.; Zacher, H.; Ashkanasy, N.M. Employee Green Behavior: A Theoretical Framework, Multilevel Review, and Future Research Agenda. Organ. Environ. 2015, 28, 103-125. [CrossRef]

44. Al-Ali Mubarak, Y.M.; Gorgenyi-Hegyes, E.; Fekete-Farkas, M. Perceived corporate sustainability practices and performance of small and medium enterprises (SMEs) in Qatar. Polish J. Manag. Stud. 2020, 22, 26-42. [CrossRef]

45. Kollmuss, A.; Agyeman, J. Mind the Gap: Why do people act environmentally and what are the barriers to pro-environmental behavior? Environ. Educ. Res. 2002, 8, 239-260. [CrossRef]

46. Wells, V.K.; Manika, D.; Gregory-Smith, D.; Taheri, B.; McCowlen, C. Heritage tourism, CSR and the role of employee environmental behaviour. Tour. Manag. 2015, 48, 399-413. [CrossRef]

47. Faizan, R.; Haque, A.U.; Cockrill, A.; Aston, J. Females at Strategic Level Affecting Logistics Firms' Competitiveness: Qualitative Comparative Analysis of Contrasting Gender in Pakistan and Canada. For. Sci. Oecon. 2019, 7, 57-71.

48. Haque, A.U.; Aston, J.; Kozlovski, E.; Caha, Z. Role of External CSR and Social Support Programme for Sustaining Human Capital in Contrasting Economies. Pol. J. Manag. Stud. 2020, 22, 147-168. [CrossRef]

49. Lo, S.H.; van Breukelen, G.J.; Peters, G.-J.Y.; Kok, G. Proenvironmental travel behavior among office workers: A qualitative study of individual and organizational determinants. Transp. Res. Part A Policy Pract. 2013, 56, 11-22. [CrossRef]

50. Ramus, C.A. Organizational Support for Employees: Encouraging Creative Ideas for Environmental Sustainability. Calif. Manag. Rev. 2001, 43, 85-105. [CrossRef]

51. Ramus, C.A.; Steger, U. The roles of supervisory support behaviors and environmental policy in employee 'ecoinitiatives' at leading-edge European companies. Acad. Manag. J. 2000, 43, 605-626. [CrossRef]

52. Steg, L.; Vlek, C. Encouraging pro-environmental behaviour: An integrative review and research agenda. J. Environ. Psychol. 2009, 29, 309-317. [CrossRef]

53. De Roeck, K.; Farooq, O. Corporate Social Responsibility and Ethical Leadership: Investigating Their Interactive Effect on Employees' Socially Responsible Behaviors. J. Bus. Ethic 2018, 151, 923-939. [CrossRef]

54. Muangmee, C.; Dacko-Pikiewicz, Z.; Meekaewkunchorn, N.; Kassakorn, N.; Khalid, B. Green Entrepreneurial Orientation and Green Innovation in Small and Medium-Sized Enterprises (SMEs). Soc. Sci. 2021, 10, 136. [CrossRef]

55. Szczepańska-Woszczyna, K.; Kurowska-Pysz, J. Sustainable Business Development Through Leadership in SMEs. Èkon. Zarz. 2016, 8, 57-69. [CrossRef] 
56. Norton, T.A.; Zacher, H.; Parker, S.L.; Ashkanasy, N.M. Bridging the gap between green behavioral intentions and employee green behavior: The role of green psychological climate. J. Organ. Behav. 2017, 38, 996-1015. [CrossRef]

57. Bissing-Olson, M.J.; Iyer, A.; Fielding, K.; Zacher, H. Relationships between daily affect and pro-environmental behavior at work: The moderating role of pro-environmental attitude. J. Organ. Behav. 2012, 34, 156-175. [CrossRef]

58. Boiral, O.; Cayer, M.; Baron, C.M. The Action Logics of Environmental Leadership: A Developmental Perspective. J. Bus. Ethic 2009, 85, 479-499. [CrossRef]

59. Ture, R.S.; Ganesh, M. Understanding Pro-environmental Behaviours at Workplace: Proposal of a Model. Asia-Pacific J. Manag. Res. Innov. 2014, 10, 137-145. [CrossRef]

60. Davis, M.C.; Challenger, R. Environmentally Sustainable Work Behavior. Wiley Encycl. Manag. 2013, 3, 1-10.

61. Bansal, P.; Gao, J. Building the Future by Looking to the Past. Organ. Environ. 2006, 19, 458-478. [CrossRef]

62. Hoffman, A.J.; Bansa, P.l. Retrospective, perspective, and prospective: Introduction to the Oxford handbook on business and the natural environment. In The Oxford Handbook on Business and the Natural Environment; Hoffman, A.J., Bansa, P.L., Eds.; Oxford University Press: Oxford, UK, 2012.

63. Molina-Azorin, J.; López-Gamero, M.; Tarí, J.; Pereira-Moliner, J.; Pertusa-Ortega, E. Environmental Management, Human Resource Management and Green Human Resource Management: A Literature Review. Adm. Sci. 2021, 11, 48. [CrossRef]

64. Ababneh, O.M.A. How do green HRM practices affect employees' green behaviors? The role of employee engagement and personality attributes. J. Environ. Plan. Manag. 2021, 64, 1204-1226. [CrossRef]

65. Dwyer, R.; Lamond, D.; Molina-Azorin, J.F.; Claver-Cortes, E.; Lopez-Gamero, M.D.; Tari, J.J. Green management and financial performance. Manag. Dec. 2009, 47, 1080-1100.

66. Albertini, E. Does Environmental Management Improve Financial Performance? A Meta-Analytical Review. Organ. Environ. 2013, 26, 431-457. [CrossRef]

67. Claver-Cortés, E.; López-Gamero, M.D.; Molina-Azorín, J.F.; Zaragoza-Sáez, P.D.C. Intellectual and environmental capital. J. Intellect. Cap. 2007, 8, 171-182. [CrossRef]

68. Chen, Y.-S. The Positive Effect of Green Intellectual Capital on Competitive Advantages of Firms. J. Bus. Ethic 2007, 77, 271-286. [CrossRef]

69. López-Gamero, M.D.; Zaragoza-Sáez, P.; Claver-Cortés, E.; Molina-Azorín, J.F. Sustainable development and intangibles: Building sustainable intellectual capital. Bus. Strat. Environ. 2011, 20, 18-37. [CrossRef]

70. Young, W.; Davis, M.; McNeill, I.M.; Malhotra, B.; Russell, S.; Unsworth, K.; Clegg, C.W. Changing behavior: Successful environmental programmes in the workplace. Bus. Strategy Environ. 2015, 24, 689-703. [CrossRef]

71. Ruepert, A.; Keizer, K.; Steg, L.; Maricchiolo, F.; Carrus, G.; Dumitru, A.; Mira, R.G.; Stancu, A.; Moza, D. Environmental considerations in the organizational context: A pathway to pro-environmental behaviour at work. Energy Res. Soc. Sci. 2016, 17, 59-70. [CrossRef]

72. Boiral, O.; Raineri, N.; Talbot, D. Managers' Citizenship Behaviors for the Environment: A Developmental Perspective. J. Bus. Ethic 2016, 149, 395-409. [CrossRef]

73. Adams, E.J.; Esliger, D.W.; Taylor, I.M.; Sherar, L.B. Individual, employment and psychosocial factors influencing walking to work: Implications for intervention design. PLoS ONE 2017, 12, e0171374. [CrossRef] [PubMed]

74. Paillé, P.; Boiral, O.; Chen, Y. Linking environmental management practices and organizational citizenship behaviour for the environment: A social exchange perspective. Int. J. Hum. Resour. Manag. 2013, 24, 3552-3575. [CrossRef]

75. Lamm, E.; Tosti-Kharas, J.; King, C.E. Empowering Employee Sustainability: Perceived Organizational Support Toward the Environment. J. Bus. Ethic 2015, 128, 207-220. [CrossRef]

76. Lasrado, F.; Zakaria, N. Go green! Exploring the organizational factors that influence self-initiated green behavior in the United Arab Emirates. Asia Pac. J. Manag. 2019, 37, 823-850. [CrossRef]

77. Jabbour, C.J.C. How green are HRM practices, organizational culture, learning and teamwork? A Brazilian study. Ind. Commer. Train. 2011, 43, 98-105. [CrossRef]

78. Dang, T.M.H.; Tran, T.T.H.; Tran, A.H. High-performance human resource management practices and creative organizational climate effects on manufacturing industry performance. Pol. J. Manag. Stud. 2020, 23, 72-89.

79. Graves, L.M.; Sarkis, J.; Gold, N. Employee proenvironmental behavior in Russia: The roles of top management commitment, managerial leadership, and employee motives. Resour. Conserv. Recycl. 2018, 140, 54-64. [CrossRef]

80. Trudel, L.; Simard, C.; Vonarx, N. La recherche qualitative est-elle nécessairement exploratoire. Rech. Qual. 2006, 5, 38-55.

81. Gioia, D.A.; Corley, K.G.; Hamilton, A.L. Seeking qualitative rigor in inductive research: Notes on the Gioia methodology. Organ. Res. Methods 2013, 16, 15-31. [CrossRef]

82. Malhotra, N.K.; Dash, S. Marketing Research: An Applied Orientation; Pearson: Bengaluru, India, 2016.

83. Agarwal, S.; Lenka, U.; Singh, K.; Agrawal, V.; Agrawal, A.M. A qualitative approach towards crucial factors for sustainable development of women social entrepreneurship: Indian cases. J. Clean. Prod. 2020, 274, 123135. [CrossRef]

84. QS University Rankings by Location. In QS Top Universities; 2019. Available online: https:/ /www.topuniversities.com/universityrankings / world-university-rankings/2019 (accessed on 19 August 2021).

85. UI GreenMetric. UI GreenMetric World University Rankings; 2018. Available online: https://greenmetric.ui.ac.id/ (accessed on 18 August 2021).

86. Sheriff, N.M.; Abdullah, N. Research universities in Malaysia: What beholds? Asian J. Univ. Educ. 2017, 13, 35-50. 
87. Brewis, J. The Ethics of Researching Friends: On Convenience Sampling in Qualitative Management and Organization Studies. Br. J. Manag. 2014, 25, 849-862. [CrossRef]

88. Rahman, M.; Billah, M.; Hack-Polay, D. What is hindering change? Anticipating the barriers to the adoption of enzyme-based textile processing in a developing country. Bus. Strat. Dev. 2019, 2, 137-147. [CrossRef]

89. Woiceshyn, J.; Daellenbach, U. Evaluating inductive vs deductive research in management studies: Implications for authors, editors, and reviewers. Qual. Res. Organ. Manag. Int. J. 2018, 13. [CrossRef]

90. Dharmesti, M.; Merrilees, B.; Winata, L. I'm mindfully green: Examining the determinants of guest pro-environmental behaviors (PEB) in hotels. J. Hosp. Mark. Manag. 2020, 29, 830-847. [CrossRef]

91. Islam, T.; Khan, M.M.; Ahmed, I.; Mahmood, K. Promoting in-role and extra-role green behavior through ethical leadership: Mediating role of green HRM and moderating role of individual green values. Int. J. Manpow. 2020, 42, 1102-1123. [CrossRef] 